\title{
Aesthetic Properties of the Art of Painting: Subjective or Objective?
}

\author{
Davor Pećnjak*
}

In this text, the ongoing debate about the realization of aesthetic properties in artworks, focusing primarily on painting as an exemplary kind of art, is reviewed. The question is whether the aesthetic properties are objective properties of the artworks themselves or subjective projections of our experiences onto the artworks. The main aim of the text is to show that properties that are considered as aesthetic properties are constituted by both objective facts about artworks and subjective projections at the same time.

\section{Introduction}

People are very familiar with art. However, historical and philosophical reflections on art show that people are perhaps less familiar with what art is than they think. This is not surprising, because art is a vast field and has many kinds and forms. Many questions can be raised about art itself and specific artworks. One of the main questions about artworks is the question about their specific properties, about properties they have exactly as artworks. These specific properties are called "aesthetic properties." It is considered that all, or most, artworks have aesthetic properties. Yet, there is an old and ongoing debate about the nature of aesthetic properties, ${ }^{1}$ including whether they are objective or subjective, whether we detect their inherent properties as objects and entities, or whether we project our own subjective states of the mind or soul as if they are properties of artworks. ${ }^{2}$ Due to this debate, it seems interesting to review some thoughts about these matters. However, there is no pretense that what is said is something original or new; rather, what will be said about these matters is only something from a slightly different point of view.

The first serious arguments about art concerning the western tradition were laid down by Plato ${ }^{3}$ and, subsequently, Aristotle. ${ }^{4}$ We shall not go into

*Research Fellow, Institute of Philosophy, Croatia.

1. It is of interest here and it will be talked of aesthetic properties only of artworks as intentionally made artefacts, though nature can have aesthetic properties as well; but, at least in some ways, nature may differently realize them than they are realized in artworks.

2. Noël Carroll, Philosophy of Art (London and New York: Routledge, 1999), 189-199; Gregory Currie, An Ontology of Art (New York: St. Martin's Press, 1989), 19, 20, 25, 40, 41.

3. Plato put forward his philosophy of art mainly in Ion, trans. Harold North Fowler, and W. R. M. Lamb (Cambridge, Mass.: Harvard University Press, 1925), and Republic, vol 1. and 2 (books 2, 3 and 10), trans. Chris Emlyn-Jones and William Predy (Cambridge, Mass.: Harvard University Press, 2013).

4. Aristotle, On Poetry and Style, trans. G. M. A. Grube (Indianapolis: Hackett, 1958). 
discussion and development of their views, ${ }^{5}$ but instead will only provide the basics for introductory purposes. Plato did not have a very high opinion of art, because he viewed art primarily from the general ontological and epistemological, and not aesthetic, viewpoint. Aesthetic considerations were secondary for him and perhaps even more negative than the first two mentioned. Even if we are not platonic thinkers, if we look at art with only an epistemological eye, we would not find much in it that can aid, improve or enhance our knowledge of the world substantially. ${ }^{6}$ Philosophy, theology and science are much more suited to this aim than art. However, Plato's main reason stems very sensibly and logically from his ontological theory. There are universal, eternal, abstract and perfect forms or ideas of entities, and the material entities that inhabit our world are imperfect reflections of these forms or ideas. They are "second" in degree. Forms or ideas are, of course, first in ontological ranking, because they are perfect and incorruptible.

Art objects like poetry, painting or drama are thus only imitations of material objects or events that surround us and that are contents of the world. Thus they are imitations of imitations, only "third" in degree, and going even further from ideal forms and ideas. Since the goal is to know and understand the forms and ideas, going further from them hardly can help us in knowing them. By this standard, art is not worth engaging $i^{7}-$ for anyone either as a producer or a consumer. It is interesting that Plato never considered the idea that there could be a universal, eternal, abstract and perfect form for each singular art object (regardless of art form). Perhaps it can be explained with the notion of parsimony - since painting and drama, for example, imitate objects and events that happen in everyday life, it is enough that there are forms of these ordinary objects. Still, paintings for example, have specifically conceived compositions of how they arrange and represent objects, which are not contained in the forms of these very objects themselves.

Today, there are theories that certain artworks themselves, or even certain kinds of art, are abstract entities. ${ }^{8}$ For instance, Dodd ${ }^{9}$ and Levinson ${ }^{10}$ argue

5. For Plato, see Christopher Janaway, Images of Excellence: Plato's Critique of the Arts (Oxford: Oxford University Press, 1995).

6. Of course, today we do not think that art's purpose is gaining new knowledge. In many other historical periods, old Greece included, this was very different - art was considered as one of the possible means for gaining or transmissing the knowledge. See Derek Matravers, Introducing Philosophy of Art in Eight Case Studies (Durham: Acumen, 2013), 117-135.

7. Beside limited value of strengthening the patriotic feelings and gaining the sense of rhythm and harmony.

8. For various views and relationships about art and abstract objects, see Christy Mag Uidhir (Edn.), Art and Abstract Objects (Oxford: Oxford University Press, 2012).

9. Julian Dodd, Works of Music (Oxford: Oxford University Press, 2007). 
that musical compositions are abstract entities; Currie ${ }^{11}$ and David Davies ${ }^{12}$ argue that in fact all entities that are artworks are in a way also abstract entities - certain types of action, and, as types, they are abstract entities (Davies is less explicit on this matter). But then, if some works of art are abstract entities, then it is questionable how can they have aesthetic properties at all, because aesthetic is primarily perceptual. Of course, one answer could be that token performances of otherwise abstract entities can have sensible, perceptual and, if appropriately combined, designed and performed, aesthetic properties. Still, the question remains how can abstract entities, which do not have causal powers, causally influence even performing - what could be the connection between abstract entity and a token performance of it? How can an abstract entity be performed at all? Even if some kinds of art or artworks are truly abstract entities, many other kinds of art, and even perhaps performances of abstract artworks, certainly have aesthetic properties.

\section{Conceiving of Aesthetic Properties}

A description of how aesthetic properties are conceived follows, through which it will be clear that there can be a full description of "how matters are" (concerning aesthetic properties) without anyone being able to definitely say whether aesthetic properties are subjective or objective. Thus, perhaps it does not matter, or, an answer may be that aesthetic properties have both subjective and objective aspects, which are perhaps even inseparable, at the same time. ${ }^{13}$

Let us take an example of a certain property which obviously is an aesthetic property. Certainly beauty seems to be par exellence an example of a property which is an aesthetic property, regardless of what it may truly be in fact. ${ }^{14}$ Besides beauty, which first comes to mind as an aesthetic property, when we speak about art and artworks, examples of other aesthetic properties are balance, symmetry,

10. Jerrold Levinson, Music, Art and Metaphysics (Oxford: Oxford University Press, 2011), 63-88, 215-263.

11. Currie, An Ontology of Art.

12. David Davies, Art as Performance (Malden: Blackwell, 2004).

13. Perhaps we may say that "aesthetic" properties supervene at the same time, both, on mental and non-mental facts or properties. We can say, perhaps, when certain facts, both mentally and non-mentally obtain, then we have an aesthetic property realized. But I shall not pursue supervenience theory of aesthetic properties in any form here. About supervenience in artworks see for example Levinson, "Aesthetic Supervenience."

14. For various theories of beauty see, for example, St. Thomas Aquinas, Summa Theologica, trans. Fathers of the English Dominican Province (Benziger 1947), 33, 270; Immanuel Kant, Kritika moći suđenja (Critique of Judgement) trans. Viktor Sonnenfeld (Naprijed: Zagreb, 1976), 45-50; Nick Zangwill, The Metaphysics of Beauty (Ithaca, NY: Cornell University, 2001). 
elegance, gracefulness, and unity. ${ }^{15}$ Of course, there are still other valuable aesthetic properties. Each of these properties may pose a problem for itself - it can be asked what it is in fact and what it is in relation to other aesthetic properties. There is no need to analyze in detail the specificity of each aesthetic property and various possible specific realizations of each property. On the other hand, of course, it will be necessary to say something about some property, but it is not necessary to go into depth for each property. The primary aim of this text is to examine some basics concerning relations of various aesthetic properties. In doing this, by necessity we must also examine and consider the relations aesthetic properties have to other properties which are not aesthetic.

There are two ways of examining: top-down and bottom-up. It may be, for example, stipulated that beauty is the highest aesthetic property an artwork may have, and we may struggle to see in a downward way what (stipulated) beauty consists of. We could also take ordinary properties of art objects qua objects like any other object in our world and try to see how these properties build up or are put together to embrace or constitute properties of the kind we call "aesthetic" properties. Of course, both ways, if possible, should come to the same conclusion, especially if there is a unique construction of the relations of ordinary properties and "aesthetic" properties. Here, "unique" should not be taken literally, meaning "only one" or "just a small number," but only logically or explanatory - that there can be a coherent way to explain and relate various kinds of properties as simply as possible. This way can be even generic in the sense that it could allow aesthetic properties, or at least some of them, to be realized in a multitude of ways. This is a potential advantage of such an explanation, because many different artworks are considered beautiful.

Therefore, it seems that beauty can be achieved, concerning individual artworks, in various ways, but something seems to be characteristic and shared between all those individual manifestations. If explanation should be generic, then some kind of underlying structure of achieving beauty should be common, and that structure should have a generic capability that would enable a multitude of individual concrete paths to achieving beauty (or any other aesthetic property). It should also to be such that we can demarcate those structures or entities which are beautiful from those which are not. It may be said for now provisionally, that beauty would be structure in the structure. That generic capability should be in

15. As examples for various approaches to aesthetic properties, see Frank Sibley, "Aesthetic Concepts," in Aesthetics and the Philosophy of Art, ed. Peter Lamarque and Stein Haugom Olsen (Malden: Blackwell, 2004), 127-141; Kendall L. Walton, "Categories of Art," in Aesthetics and the Philosophy of Art, ed. Peter Lamarque and Stein Haugom Olsen (Malden: Blackwell, 2004), 142-157; Robert Stecker, Aesthetics and the Philosophy of Art (Lanham: Rowman and Littlefield, 2010), 65-92; Peter Lamarque, "Aesthetic Empiricism," in Work and Object, ed. Peter Lamarque (Oxford: Oxford University Press, 2010), 122-138. 
fact something like a schema and should have an ability to generate certain aesthetic properties when appropriately filled with its elements.

From the above, it can be provisionally concluded that the beauty of an artwork emerges from its having some other aesthetic properties laid out, combined and composed in a certain way. This leads to thinking that, if true, among other relations, there is a certain hierarchy of aesthetic properties. Again, if this is true, then it implies that there are "higher-order" aesthetic properties and more basic aesthetic properties. Further, some more basic aesthetic properties depend on certain arrangements of various non-aesthetic properties, and perhaps, not only on them, but also on psychological states and processes of experiences of artworks as well. By the hierarchy of aesthetic properties, we mean in ontological terms and not in terms of value.

Taking painting as an example, a theory will be created about aesthetic properties considering this kind of art, but it seems that this could be extended, with necessary adjustments, to other kinds of art as well. If not, then at least it is applicable to painting, thus fulfilling the aim of this text, which is to show that, at least for the art of painting, there can be a full description of how aesthetic properties are realized without saying definitively whether they are subjective or objective. There can be, in fact, a case which enables us to say that aesthetic properties are complex composite entities, so their realization depends on simultaneously present subjectivity and objectivity.

\section{Architectonic of Aesthetic Properties}

That being settled, some kind of architectonic of properties for artworks in the domain of painting can be made. Using a bottom-up approach, the description begins with a basic fundamental layer that contains properties which are certainly and unproblematically non-aesthetic, i.e. they are some common ordinary properties of objects.

First, there is some physical foundation on which the paint will be laid. It is usually a wooden plate, canvas or a wall (in the case of frescoes). There can be other kinds of foundations as well. Then, patches of colors are laid on the prepared foundation; some of the patches are so thin that we can consider them as lines (colored). It could be the case that basic drawing, as an elementary scheme, precedes putting the patches of colors. Colors can be, and often are, mixed and placed in layers in order to achieve various nuances, brightness and effects. After enough color is put down on a foundation, the painting is finished and it is let to dry. Of course, some amendments can be made afterwards but nothing essentially new happens. After the painting has dried, it can be shown to the public.

What happens now, when the public is looking at the painting? Certain amount of photons fall on the painting; some wavelengths are absorbed, some 
reflected, and those that are reflected travel under normal conditions to the eye of the beholder. ${ }^{16}$ Light is refracted through the lens, falls on the retina and is transformed into the electrical impulses that travel through optical nerves further to the brain and, finally, cause states and processes in the various visual areas of the brain. We should add, because we are dualists, that these are a further cause of some non-physical mental states and processes, but nothing depends on this further claim; nothing we shall say here about hierarchy and the architectonic of properties, both aesthetic and non-aesthetic, depends on the dualist picture of the mind. Particular instantaneous sensations are integrated into a percept so they all combine to give a structured visual perception (of the painting). Ultimately, the beholder has a perceptive experience of the painting.

\section{Origin, Properties and Different Layers}

What are the origins of a painting? Of course, paintings are produced through complex intentional processes, using various physical processes, which consist in many subprocesses. Broadly speaking, these count as part of the history of production. Author(s), or in our case painters, use their various skills, knowledge and imagination in this intentional production of a work. It sounds simple, but it is not - indeed, there are rather complex relationships between these factors.

Thus, it seems that there are many states and processes, both physical and psychological, of different levels and of different ontological characterizations and layers. All of these are inescapable if we would like to give a full and precise characterization of what the aesthetic properties of artworks are, and in this article, primarily paintings, and how they are realized. On a nonperceptible level, the colors of a painting are merely various chemical substances compounds and mixtures. For example, in an oil painting, color is in fact a mixture of some oil, most commonly nut, linseed or poppy oil with pigments, natural or artificial - as are, for example, Chromeoxid green $\left(\mathrm{Cr}_{2} \mathrm{O}_{3}\right)$, Vermilion ( $\mathrm{HgS}$ ) (Figure 1), Naples yellow $\left(\mathrm{Pb}(\mathrm{SbO})_{2}\right)$ (Figure 2) or Prussian blue $\left(\mathrm{Fe}_{4}\left[\mathrm{Fe}\left(\mathrm{CN}_{6}\right)_{3}\right]\right)$ (Figure 3). ${ }^{17}$

16. For some details and, in fact, a different overall approach, see Alberto Marinho Ribas Semeler, "Neuroaesthetics: Aesthetic in a Naturalistic Perspective of Art Philosophy," Athens Journal of Humanities and Arts 4 no. 4 (2017).

17. Davor Žilić, Tajne uljane boje (The secrets of oiled colors) (Petrinja: Vlastita naklada, 2008), 27, 30, 32, 34. 


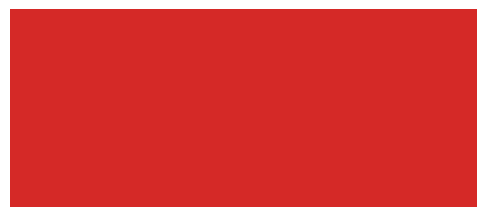

Source: https://bit.ly/2JQHuGB.

Figure 1. Vermillion

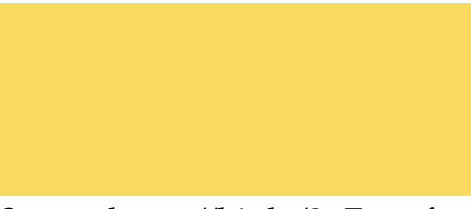

Source: https://bit.ly/2qFnyyf.

Figure 2. Naples Yellow

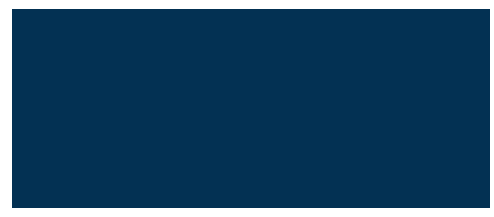

Source: https://bit.ly/2EWd0PM.

Figure 3. Prussian Blue

Human beings, of course, are not able to perceive the structure and shape of molecular orbitals of these compounds; they do not have a perceptible access to molecules. Despite this, they are aware of the quality, which is having a subjective visual experience and importantly, but only partly, depends on molecular orbitals - because their specific energetic levels and their fulfillment with electrons determine which energies of the incoming photons will be absorbed and which reflected. ${ }^{18}$ Further, human beings do not see photons which are reflected, human beings do not see what happens in their eyes, and they do not see what happens in their brains - in other words, human beings do not see these physical and physical-chemical processes. Human beings are not even directly aware of them. What they are aware of, and what these primary processes in fact produce, are subjective qualitative experiences called colors. ${ }^{19}$ Through that experience, it seems to us that the surface of a painting bears various color patches. At each square millimeter of a painting, there is a certain (color) patch. It can be said that human beings see colored surface areas (at the bottom level, of course; we see much more, but at higher levels of integrating

18. James Brady and Gerard Humiston, General Chemistry, 3rd ed. (New York: Wiley, 1982), 73-78, and chapter 5.

19. About primary and secondary qualities and properties, and about subjectivity, see Colin McGinn, The Subjective View (Oxford: Clarendon Press, 1983); for psychology of vision see Robert Sekuler and Randolph Blake, Perception, 3rd ed. (New York: McGrawHill, 1994), chapters 2-6. 
experiences). So at the first level, even bare color experience is dependent on two principal factors: on the physical-chemical properties of compounds and mixtures, or more precisely, on their molecular properties, and on the specific construction of our perceptual apparatus, which, as a final product, delivers exactly these experiential qualities. Should that apparatus be different, the subjective qualities of these experiences would also be different, even without altering the source, namely the chemical substances laid on the canvas, wood or any other foundation. This already suggests that further aesthetic properties would be dependent both on objective features and subjective features.

\section{Basic Properties, Aesthetic Properties, Experiences and Cognition}

Namely, for perception to exist, there has to be a perceiver; for experience to exist, there has to be an experiencer. However, the perceiver and experiencer are subjects with their own subjective, special apparatuses. These apparatuses, which deliver a special kind of point of view on matters from the outside world, are thus apparatuses for a production of a certain kind of subjectivity. We can imagine that there could be an infinite number of such apparatuses, or, at least, very many, where each delivers a different subjective quality of perception or experience from the same outer source. Therefore, the aforementioned chemical substances, Chromeoxid green $\left(\mathrm{Cr}_{2} \mathrm{O}_{3}\right)$, Vermilion $(\mathrm{HgS})$, Naples yellow $\left(\mathrm{Pb}(\mathrm{SbO})_{2}\right)$ or Prussian blue $\left(\mathrm{Fe}_{4}\left[\mathrm{Fe}\left(\mathrm{CN}_{6}\right)_{3}\right]\right)^{20}$ on a canvas, can be seen very differently by perceivers with different perceiving apparatuses. This means that even the basic quality of experiencing the color depends on the special structure of the perceiving apparatus.

Imagine that you have more than one such experiencing apparatus and that you can switch from one to another, retaining the memories of how the outside world looks with each of them. Then you can perhaps reach the conclusion that the same painting, as a physical object which is one and retains its identity, is still very different aesthetically under different experiencing apparatuses. That would mean not only that "secondary" properties of objects, like colors, depend on subjective apparatuses, but also that further aesthetic properties, which depend on such "secondary" properties, also partly depend on one's own subjectivity. Of course, that shows that even when we do not have more than one perceiving apparatus, aesthetic properties that arise from colors depend partly on subjectivity. Here, it is just warned that perceiving bare colors (on the canvas or any other foundation) still does not give rise to an aesthetic property itself (of the work or about the work). Only when perceptively integrating their variety over the area of a foundation

20. Žilić, Tajne uljane boje. 
can we start to talk about the possibility of emerging aesthetic properties. Internally, in the soul (mind) of the perceiver, a percept, caused by various chemical substances and the specificity of the physiological/psychological apparatus, which cause a visual experience of colors, uses input information for further workings of the powers of the soul or capabilities of the mind, which will deliver recognition of the more complex forms, such as the content and meaning of a painting.

There can be, at least, two levels of recognition of the content of paintings. Take, for example, your favorite painting from high renaissance, mannerism or baroque. There can be a basic level recognition of elementary things presented or represented; taking our example, this could be that there are human beings in the painting, clothed such-and-such, in such-and-such relative positions; that there are some other objects represented in the painting also, and so on. At a more sophisticated level, we find that we recognize who these persons are and what they are doing; what the other objects are; and if there is a definite event portrayed, then we recognize what that event is. The most sophisticated level is to read the whole story and symbolism of the painting, more or less how it is intended by the author (and in many cases, by a patron or client of the painter also). ${ }^{21}$ It is not needed to dwell on discussion of whether and how much the intentions of the author (and the client) are relevant to an overall interpretation of the painting, because they are the source from which the painting's content emerges; and it is exactly as such put on the canvas, wooden plate or other surface. At a more sophisticated level, e.g. to recognize which persons are in the painting, knowing some contextual features is necessary. Some of these contextual features are learned and the knowledge about them consists of and is represented in propositional form.

Propositional form means that our knowledge is represented in the soul/ mind in the form of propositional attitudes like belief. It has a form $A$ believes $S$, where $A$ is a subject, belief is an attitude (taking $S$ as true), and $S$ is a placeholder for inserting a proposition. Propositions have concepts as their constituents, and propositions and concepts are expressed as sentences, phrases and words (in some natural language). ${ }^{22}$ It is contrasted to perceptual comprehension of the world. Perception depends on our senses and on mechanisms of integrating these sensual data into percepts, which have a different structure than propositional statements. ${ }^{23}$

21. Michael Baxandall, Painting and Experience in Fifteenth-Century Italy (Oxford: Oxford University Press, 1972), 3-27.

22. For various conceptions of belief, see Radu Bogdan (Edn.) Belief (Oxford: Clarendon Press, 1986).

23. See more details in Tomislav Janović and Davor Pećnjak, "Perceptual and Conceptual Content of Human Consciousness - A Perspective of the Philosophy of Mind," Collegium Antropologicum 25 (2001). 
We learned in some propositional form, for example, about St. Mary, Holy Mother of God, and certain other saints, what they did in their lives, where they lived, what their signs and attributes were. Part of that learning was done also by seeing the examples of paintings. So, what we know in the propositional form is very important for recognizing what exactly is in the painting. Because we can easily connect knowledge in propositional form with perception or visual imagination, we apply that knowledge when we observe and analyze the content and meaning of a certain painting. Thus, we might also say that there is a two way recognition process between perception and appropriate propositional knowledge related to what perceptual contact with the painting has elicited or caused as an experience. Visual perception and experience, concerning artworks, can be sources of information that cause the retrieval of certain knowledge (stored previously) in propositional form, which can then be appropriately applied to describe what is perceived. Then we can have an understanding of what is in the painting.

Certain propositional understanding of what is in the painting can enable the viewer to see even formal characteristics (and perhaps various other aesthetic properties) of the painting in a better way, for example, how appropriate they are. What is meant here to say is that recognizing the content and having an understanding of the characters, objects and plot of the painting, can enable the viewer to see some formal characteristics in a new way: that they are in fact aesthetically even better (or worse) than we thought before.

As such, the existence or quality of certain aesthetic properties can sometimes depend on the characters, events, story and plot which are presented. This means that aesthetic properties are closely connected and dependent on propositional knowledge, i.e. they could be dependent on what we know. However, propositional knowledge is a contextual feature. Accordingly, aesthetic properties can depend on appropriate contextual features also. Yet, because of that, the artists and the public must have more or less common knowledge of various facts, stories, histories and (re)presentational systems both for making and for "reading" paintings, in order for the art of painting to be successful in its mutual communication between the artists and the public when artworks are exhibited.

\section{Relations of Subjectivity and Objectivity}

Having established some understandings of these properties, we can now apply what has been said to some examples of the so-called aesthetic properties. Is symmetry, as an aesthetical property, objective or subjective? Take a high 
renaissance painting, ${ }^{24}$ let's say, of the type sacra conversazione, where the Holy Mother of God is in the middle and one of the saints or groups of saints are on the right and left of her symmetrically (Figure 4).

Starting from the lowest level, there are patches of various colors across the whole of the foundation. Objective physical chemical properties, and frequency and wavelengths of light which stem from the painting, can be measured and determined, but numbers would give us perhaps nothing aesthetically significant at all. On average, the figures (quantitative data, not the persons depicted) and measurements conclude that there are some symmetrical arrangements of the patches, taking the axis of the symmetry in our example to be the middle. However, this is still not yet an aesthetic property of symmetry. It is objective because the chemical and physical entities measured are symmetrically present on the foundation in twodimensional space, but this does not give rise to aesthetics immediately. Symmetry in the painting could be regarded as an aesthetic property yet for the following reason: we have subjective experiences of the very colors with boundaries of these patches, and our past experience of the world, together with some knowledge which signals representations of persons and objects. So, a single aesthetic property depends on various factors and features.

Of course, not all paintings have symmetry; some are definitely asymmetric, such as mannerist paintings, for example. In both paintings that are symmetrical and asymmetrical, features of composition (in mannerist paintings, saturation with movement or elongated shapes) which are diverse tend to be elements for another aesthetic property - namely unity. In symmetrical compositions, these symmetries combine into a further property of unity, so it may be said that unity depends on symmetry; but, in mannerist paintings the unity of plot, story and formal composition will be dependent on asymmetrical and elongated shapes (and on some other features as well). Further, in symmetrical compositions for example, unity is a higher-order aesthetic property stemming from the lower-level property of symmetry. Still further, symmetry is partially dependent on some non-aesthetic properties, as are layered patches of chemical substances that give rise to color experiences.

24. For high renaissance see Linda Murray, The High Renaissance and Mannerism (London: Thames and Hudson, 1993). For iconology see for example Branko Jozić, Riječ u slici: Repertorij kršćanske ikonografije (Word in Picture: Repertoire of Christian Iconology) (Split: Književni krug Split, 2009); Radovan Ivančević, "Uvod u ikonologiju" (Introduction to Iconology), in Leksikon ikonografije, liturgike $i$ simbolike zapadnog kršćanstva (Lexicon of Iconography, Liturgics and Symbolics of Western Christianity), ed. Anđelko Badurina (Zagreb: Kršćanska sadašnjost, 1990), 13-82. 


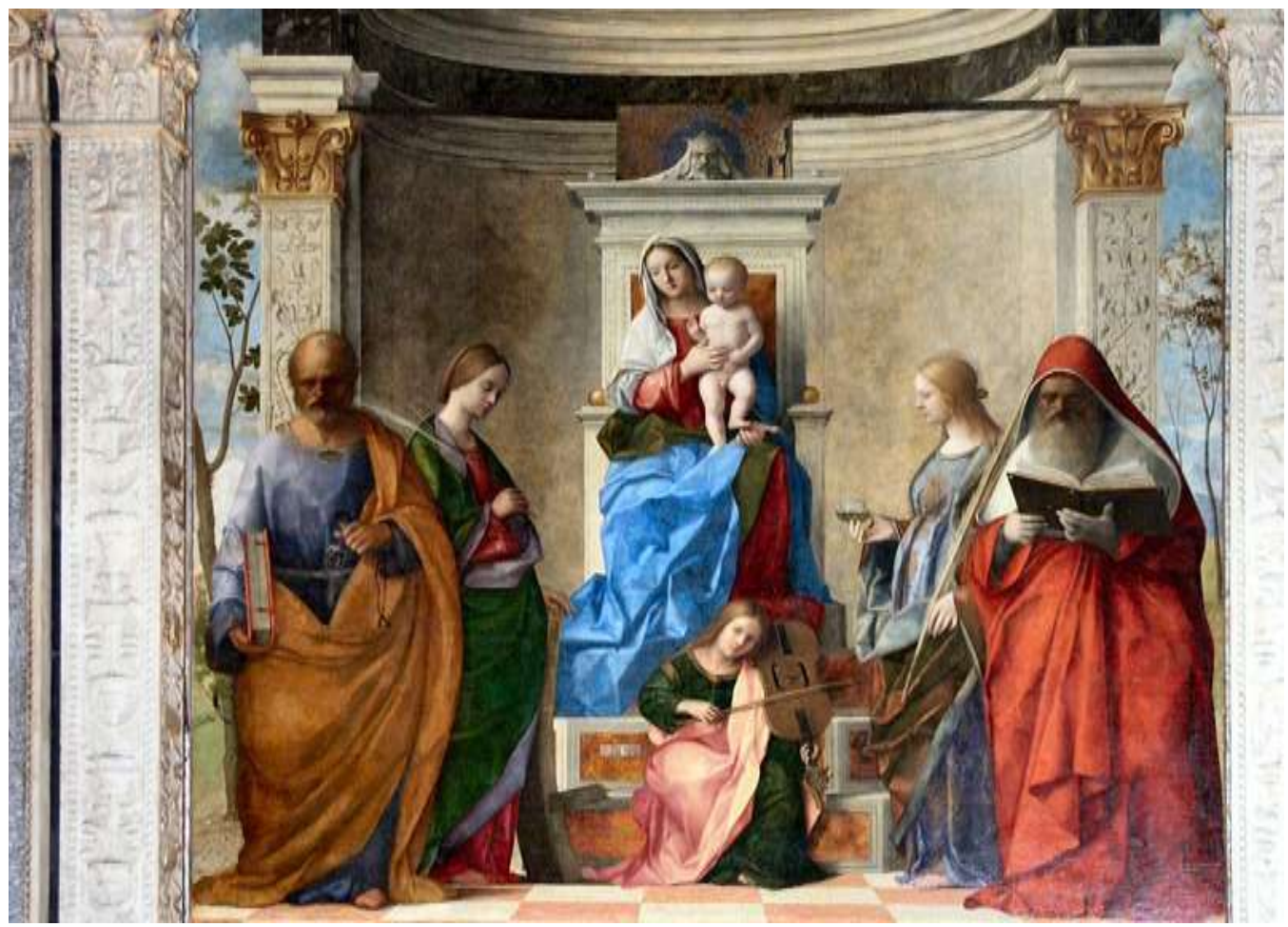

Source: https://bit.ly/2HtZvtv.

Figure 4. Giovanni Bellini "Sacra conversazione," oil on canvas (transferred from wood), 402x273, (1505), now in San Zaccaria church in Venice.

If colors are secondary properties, then symmetry or other properties that depend on color patches and on the experience of colors would be third-order properties; still further, if there would be properties constituted by third-order properties, as unity could be constituted by symmetries (and not only by symmetries, but also by some other properties or features), then unity and other such properties would be fourth-order properties. This suggests that aesthetic properties are not only dependent on non-aesthetic properties, but also that some aesthetic properties are dependent on other aesthetic properties i.e. that there is a certain hierarchy of aesthetic properties themselves.

If it could be accepted that there could be such a hierarchy of aesthetic properties, then it seems that beauty, as an aesthetic property, could be an aesthetic property of the highest rank and order. It could be constituted by one or more lower-level aesthetic properties, or it can be said that when some aesthetic properties are constituted in an artwork in such-and-such manner, then they together constitute the beauty of that artwork. If this reasoning is sound, how exactly this relationship could work is a subject for further analysis not provided here. 


\section{Conclusion}

From all that is said above, it is strongly suggested that various aesthetic properties depend on subjectivity, as well as on objective features at the same time. Thus, aesthetic properties are neither merely objective nor merely subjective; they are neither only projected nor only detected, but both or all at the same time. Moreover, sometimes contextual features will be important as constituents of certain particular aesthetic properties. To put it in a more picturesque language, artworks are entities with subtle interplay of subjective \& objective features and properties, and that interplay gives rise to subjective and objective parts which in fact constitute aesthetic properties.

\section{Acknowledgements}

I would like to thank the anonymous referees for Athens Journal of Humanities and Arts for their helpful comments.

\section{Bibliography}

Aristotle. On Poetry and Style. Translated by G. M. A. Grube. Indianapolis: Hackett, 1958.

Baxandall, Michael. Painting and Experience in Fifteenth-Century Italy. Oxford: Oxford University Press, 1972.

Bogdan, Radu (Edn.) Belief. Oxford: Clarendon Press, 1986.

Brady, James, and Humiston, Gerard. General Chemistry, 3rd ed. New York: Wiley, 1982.

Carroll, Noël. Philosophy of Art. London and New York: Routledge, 1999.

Currie, Gregory. An Ontology of Art. New York: St. Martin's Press, 1989.

Davies, David. Art as Performance. Malden: Blackwell, 2004.

Dodd, Julian. Works of Music. Oxford: Oxford University Press, 2007.

Ivančević, Radovan. "Uvod u ikonologiju" (Introduction to Iconology). In Leksikon ikonografije, liturgike i simbolike zapadnog kršćanstva (Lexicon of Iconography, Liturgics and Symbolics of Western Christianity), edited by Anđelko Badurina, 13-82. Zagreb: Kršćanska sadašnjost, 1990.

Janaway, Christopher. Images of Excellence: Plato's Critique of the Arts. Oxford: Oxford University Press, 1995.

Janović, Tomislav, and Pećnjak, Davor. "Perceptual and Conceptual Content of Human Consciousness - A Perspective of the Philosophy of Mind." Collegium Antropologicum 25 (2001): 657-663.

Jozić, Branko. Riječ u slici: Repertorij kršćanske ikonografije (Word in Picture: Repertoire of Christian Iconology). Split: Književni krug Split, 2009). 
Kant, Immanuel. Kritika moći suđenja (Critique of Judgement). Translated by Viktor Sonnenfeld. Naprijed: Zagreb, 1976.

Lamarque, Peter. "Aesthetic Empiricism." In Work and Object, edited by Peter Lamarque, 122-138. Oxford: Oxford University Press, 2010.

Levinson, Jerrold. Music, Art and Metaphysics. Oxford: Oxford University Press, 2011.

Matravers, Derek. Introducing Philosophy of Art in Eight Case Studies. Durham: Acumen, 2013.

McGinn, Colin. The Subjective View. Oxford: Clarendon Press, 1983.

Murray, Linda. The High Renaissance and Mannerism. London: Thames and Hudson, 1993.

Plato. Ion. Translated by Harold North Fowler, and W. R. M. Lamb. Cambridge, Mass.: Harvard University Press, 1925.

Plato. Republic, vol 1. and 2 (books 2, 3 and 10). Translated by Chris EmlynJones and William Predy. Cambridge, Mass.: Harvard University Press, 2013.

Ribas Semeler, Alberto Marinho. "Neuroaesthetics: Aesthetic in a Naturalistic Perspective of Art Philosophy." Athens Journal of Humanities and Arts 4 no. 4 (2017): 283-299.

Sekuler, Robert, and Blake, Randolph. Perception, 3rd ed. New York: McGrawHill, 1994.

Sibley, Frank. "Aesthetic Concepts." In Aesthetics and the Philosophy of Art, edited by Peter Lamarque and Stein Haugom Olsen, 127-141. Malden: Blackwell, 2004.

St. Thomas Aquinas. Summa Theologica. Translated by Fathers of the English Dominican Province. Benziger 1947.

Stecker, Robert. Aesthetics and the Philosophy of Art. Lanham: Rowman and Littlefield, 2010.

Uidhir, Christy Mag. (Edn.). Art and Abstract Objects. Oxford: Oxford University Press, 2012.

Walton, Kendall L. "Categories of Art." In Aesthetics and the Philosophy of Art, edited by Peter Lamarque and Stein Haugom Olsen, 142-157. Malden: Blackwell, 2004.

Zangwill, Nick. The Metaphysics of Beauty. Ithaca, NY: Cornell University, 2001.

Žilić, Davor. Tajne uljane boje (The secrets of oiled colors). Petrinja: Vlastita naklada, 2008. 